* Mestrando em Direitos Coletivos e Cidadania e especialista em Processo Civil pela Universidade de Ribeirão PretoUNAERP. Procurador do $\mathrm{Mu}-$ nicípio de Ribeirão Preto-SP. Email: mrmazzei@yahoo.com.br ** Mestrando em Direitos Coletivos e Cidadania pela Universidade de Ribeirão PretoUNAERP e especialista em Direito Tributário pela Universidade Anhanguera - Uniderp. Procurador do Município de Ribeirão Preto-SP. E-mail: mtlorenzi@yahoo.com

*** Doutor e Mestre em Direito pela PUC/SP. Professor de Direito do Mestrado Universidade de Ribeirão Preto/ SP - UNAERP. Professor convidado do curso presencial de pós-graduação "lato sensu" em Direito Processual Civil da Faculdade de Direito da USP Ribeirão Preto (FDRP/USP). MBA Executivo pela FGV (Fundação Getúlio Vargas). Membro efetivo e Diretor de Relações Institucionais do Instituto dos Advogados de São Paulo. E-mail: zgneto@uol.com.br

\section{A defesa de direitos coletivos e difusos através do exercício do poder de polícia municipal: 0 direito ao transporte coletivo seguro e o direito à ocupação regular do solo urbano}

\author{
A Defense OF COLLECTIVE RIGHTS AND DIFFUSE \\ BY EXERCISING POWER OF MUNICIPAL POLICE: \\ THE RIGHT TO COLLECTIVE TRANSPORT \\ INSURANCE AND RIGHT TO REGULAR OCCUPATION \\ OF URBAN LAND
}

\author{
Marcelo Rodrigues Mazzei * \\ Marcelo Tarlá Lorenzi ** \\ Zaiden Geraige Neto $* * *$
}

Resumo: O presente trabalho visa demonstrar a possibilidade da defesa de direitos difusos e coletivos pelo exercício do poder de polícia municipal independentemente da intervenção do Poder Judiciário, descrevendo-se sucintamente a competência constitucional atribuída os Municípios no campo legislativo e administrativo, abordando as características do poder de polícia e a sua utilização no âmbito municipal como instrumento de defesa de direitos difusos e coletivos, em especial do direito ao transporte coletivo seguro e do direito à ocupação regular do solo urbano.

Palavras-chave: Direitos Coletivos. Defesa. Poder Polícia. Município.

Abstract: The present work aims to demonstrate the possibility of the defense to diffuse and collective rights through the exercise of municipal police power independently of the intervention of the judiciary, describing briefly the constitutional competency of the cities to create laws, addressing the characteristics of power police and its use as a tool for defense diffuse and collective rights, in particular the right to collective transportation insurance and the right to regular occupation of urban territory.

Keywords: Collective rights. Defense. Police power. City. 


\section{INTRODUÇÃO}

O atributo da auto-executoriedade do poder de polícia sempre suscitou discussões doutrinárias sobre a sua aplicabilidade a determinadas situações, bem como sobre os seus limites.

Na busca da segurança de uma decisão judicial, muitos Municípios provocam intensa judicialização sobre questões passíveis de solução extrajudicial, atribuindo, na prática, a responsabilidade na implantação de determinada política pública ao Poder Judiciário.

Na prática, é muito comum o administrador municipal repassar ao Poder Judiciário a sua responsabilidade política na defesa dos direitos coletivos lato sensu dos seus administrados. Isso porque ainda predomina em boa parte das Prefeituras o entendimento de que o Poder Judiciário é único instrumento da solução dos conflitos existentes. Ademais, o administrador municipal atenua possíveis desgastes políticos ou responsabilidades administrativas com tal medida. Livra-se, portanto, do questionamento sobre a correção da medida adotada. Isenta-se o administrador público, também, de qualquer demora na solução do conflito.

Com efeito, seja com o intuito de obter maior segurança na conduta administrativa adotada, seja com a intenção de repassar a responsabilidade na solução do problema ao Poder Judiciário, a grande maioria dos Municípios não exerce na plenitude o atributo da auto-executoriedade do seu poder de polícia, mormente quando se trata da defesa de direitos difusos ou coletivos, cujo impacto social decorrente da atuação municipal é percebido por grande parte da população local ${ }^{1}$.

É claro que nenhum conflito está imune de ser apreciado pelo Poder Judiciário. O que se busca nesse estudo, entretanto, é justamente defender a possibilidade do Município, desde que respeitados os direitos fundamentais dos cidadãos $^{2}$, promova, através do exercício do seu poder de polícia, medidas extrajudiciais tendentes a solucionar conflitos que envolvam direitos coletivos lato sensu de sua população. Para os fins a que se propõe o presente estudo, deve-se considerar o conceito de direitos coletivos lato sensu como englobante dos direitos difusos e dos direitos coletivos stricto sensu, considerando em

\footnotetext{
1 "En la vida municipal, más que en cualquier otro ámbito, se dan los problemas de la vida cotidiana de la comunidad y es donde surgen la infinidad de fenómenos pequenos o grandes, pero contínuos, que afectan más proximamente la convivência de la población”. (PECHIR, 2007, p. 27).

${ }^{2}$ Como o direito à propriedade, ao asilo inviolável consistente no domicílio e à intimidade.
} 
especial suas características comuns, como a indivisibilidade do seu objeto e a indeterminabilidade de seus titulares.

Note-se que por derivar do direito administrativo sancionador, o exercício do poder de polícia municipal realizado com a imposição de sanções como a apreensão de mercadorias, aplicação de multas ou lacração de estabelecimentos deve obedecer ao princípio da legalidade estrita ${ }^{3}$, com a fixação prévia da conduta tida por delituosa em lei no sentido formal ${ }^{4}$, onde deverá constar também as penas e as etapas do procedimento de cominação da sanção ${ }^{5}$, cuja aplicação deve ser materializada em processo administrativo próprio que observe necessariamente os princípios da ampla defesa e contraditório ${ }^{6}$, sob pena de nulidade.

Tem-se, contudo, que algumas situações cotidianas, onde se verifique o iminente perigo de dano a direitos coletivos lato sensu, demandam do Município responsável a urgência na adoção de certas medidas concretas, independentemente da intervenção do Poder Judiciário para salvaguardar tais direitos. Igualmente, em outras situações, como forma de reduzir a intensa litigiosidade comum ao cenário jurídico brasileiro, mostra-se desnecessária a intervenção prévia do Poder Judiciário no que tange à adoção de medidas administrativas por parte do Poder Executivo Municipal para a garantia desses direitos.

A legislação fornece exemplos de medidas administrativas urgentes que podem ser tomadas sem a intervenção direta e prévia do Poder Judiciário, tal como o embargo extrajudicial de obra (art. 935 do CPC) e a ocupação de propriedade particular em caso de iminente perigo público (art. $5^{\circ}$, inciso XXV da Constituição Federal).

\footnotetext{
${ }^{3}$ Normas por meio das quais a autarquia, sem lei que o autorizasse, instituiu taxa para registro de pessoas físicas e jurídicas no Cadastro Técnico Federal de Atividades Potencialmente Poluidoras ou Utilizadoras de Recursos Ambientais, e estabeleceu sanções para a hipótese de inobservância de requisitos impostos aos contribuintes, com ofensa ao princípio da legalidade estrita que disciplina, não apenas o direito de exigir tributo, mas também o direito de punir. (STF, ADI $1823 \mathrm{MC}$, Relator Min. Ilmar Galvão, Tribunal Pleno, Julgado Em 30/04/1998, DJ 16-10-1998 PP-00006 Ement Vol01927-01 PP-00053 RTJ Vol-00179-03 PP-01004).

${ }^{4}$ Não basta a previsão da sanção e de seu procedimento em Decreto, já que esse diploma que não atende à exigência do princípio da legalidade estrita por se tratar de norma regulamentadora de uma lei previamente existente.

${ }^{5}$ STJ, EREsp no 441.573/SP, Rel. Ministro José Delgado, Rel. p/ acórdão Ministra Eliana Calmon, Primeira Seção, julgado em 23/08/2006, DJ 12/03/2007, p. 189.

${ }^{6}$ A jurisprudência deste Tribunal firmou-se no sentido de que, nos procedimentos administrativos, é necessária a observância dos princípios do contraditório e da ampla defesa, conforme assegurado pelo art. 5 LV, da Constituição (STF, ARE 728143 AgR, Relator Min. Ricardo Lewandowski, Segunda Turma, julgado em 11/06/2013, Acórdão Eletrônico DJe-121 Divulg 24-06-2013 Public 25-062013).
} 
Assim, serão analisadas no decorrer do presente artigo possíveis medidas derivadas do exercício do poder de polícia do Município para a defesa de direitos coletivos lato sensu da sua população, principalmente quando verificada a urgência da medida e os valores jurídicos em questão no caso concreto.

\section{COMPETÊNCIAS DO MUNICÍPIO}

Apesar de opiniões em contrário (SILVA, 1997, p. 450/451), o Município desde a Constituição de 1988 é considerado ente federativo dotado de autonomia política-administrativa e financeira (arts. 18, caput e 158 da Constituição Federal), com capacidade tributária para instituição de tributos próprios (arts. 145, 149-A e 156 da Constituição Federal), possuindo específico Poder Executivo (Prefeitura) e Legislativo (Câmara de Vereadores). A Constituição de 1967 não estabelecia expressamente o Município como ente federativo ${ }^{7}$, mas the atribuía autonomia pela administração própria quanto à organização dos serviços públicos locais (art. 15, inciso II, alínea "b") e quanto à instituição e arrecadação dos tributos de sua competência (art.15, alínea "a"), possibilitando inclusive a livre aplicação de suas rendas, sem prejuízo da obrigatoriedade de prestar contas e publicar balancetes nos prazos fixados em lei.

Como aponta Moraes (2002, p. 274), "a autonomia municipal, da mesma forma que a dos Estados-membros, configura-se pela tríplice capacidade de auto-organização e normatização própria, autogoverno e autoadministração".

Os incisos I a IX do art. 30 da Carta Magna estabelecem as competências atribuídas aos Municípios, como poder legislar sobre assuntos de interesse local, suplementando a legislação federal e a estadual no que couber, além de promover o adequado ordenamento territorial, mediante planejamento do parcelamento e da ocupação do solo urbano e a devida proteção do patrimônio histórico-cultural local.

Como demonstrado, as matérias que reflitam o interesse imediato do Município e não sejam matérias cuja competência normativa esteja reservada à União ou aos Estados poderão ser reguladas por lei municipal.

A conceituação de interesse local para fins do exercício da competência legislativa municipal é difícil, dando margem perigosamente ao subjetivismo interpretativo para sua definição. Como conceito aberto, tem-se que somente diante do caso concreto é possível definir seu alcance (ALVES, 2004).

\footnotetext{
${ }^{7}$ Art. $1^{\circ}$ da Constituição Federal de 1969. O Brasil é uma República Federativa, constituída sob o regime representativo, pela união indissolúvel dos Estados, do Distrito Federal e dos Territórios.
} 
Entretanto, a competência constitucional dos Municípios para legislar sobre interesse local não tem o alcance de estabelecer normas sobre assuntos cuja competência legislativa foi exclusivamente atribuída pela Constituição Federal à União ou aos Estados.

Assim, afigura-se como elemento definidor do conceito de interesse local o grau de intensidade do interesse (SILVA, 2003, p. 110) quando considerada sua influência específica sobre cada um dos entes federativos.

O Supremo Tribunal Federal por inúmeras vezes já teve oportunidade de delimitar o alcance do conceito de interesse local para fins de exercício da competência legislativa municipal, declarando ser competente o Município para fixar o horário de funcionamento de estabelecimentos comerciais ${ }^{8}$ desde que não infrinja leis estaduais ou federais válidas ${ }^{9}$, sendo possível legislar sobre o tempo de espera para os usuários dos serviços de cartórios extrajudiciais ${ }^{10} \mathrm{ou}$ sobre o tempo máximo de espera do consumidor para atendimento em instituição bancária ${ }^{11}$, bem como sobre a necessidade de instalação nessas instituições de equipamentos destinados a proporcionar segurança dos consumidores (portas eletrônicas e câmaras filmadoras) ou a propiciar conforto, mediante oferecimento de instalações sanitárias, cadeiras de espera ou colocação de bebedouros ${ }^{12}$. Igualmente, os Municípios são competentes para legislar sobre questões que respeitem a edificações ou construções realizadas no seu território, assim como sobre assuntos relacionados à exigência de equipamentos de segurança em imóveis destinados a atendimento ao público ${ }^{13}$, além da proibição do estacionamento de veículos sobre calçadas, meios-fios, passeios, canteiros e áreas ajardinadas ${ }^{14}$ e o estabelecimento de distância mínima entre postos de revenda de combustíveis ${ }^{15}$.

\footnotetext{
${ }^{8}$ Súmula 645 do STF.

${ }^{9}$ STF, AI 622.405-AgR, Rel. Min. Eros Grau, julgamento em 22-5-2007, Segunda Turma, DJ de 156-2007 e AI 729.307-ED, Rel. Min. Cármen Lúcia, julgamento em 27-10-2009, Primeira Turma, DJE de 4-12-2009.

${ }^{10}$ STF, RE 397.094, Rel. Min. Sepúlveda Pertence, julgamento em 29-8-2006, Primeira Turma, DJ de 27-10-2006.

${ }^{11}$ STF, AI 495187 AgR, Rel Min. Dias Toffoli, Primeira Turma, julgado em 30/08/2011, RE 432.789, Rel. Min. Eros Grau, julgamento em 14-6-2005, Primeira Turma DJ de 7-10-2005 e RE 357.160AgR, Rel. Min. Ayres Britto, julgamento em 13-12-2011, Segunda Turma, DJE de 23-2-2012.

${ }^{12}$ STF, AI 347.717-AgR, Rel. Min. Celso de Mello, julgamento em 31-5-2005, Segunda Turma, DJ de 5-8-2005.

${ }^{13}$ STF, AI 491.420-AgR, Rel. Min. Cezar Peluso, julgamento em 21-2-2006, Primeira Turma, DJ de 24-3-2006.

${ }^{14}$ STF, RE 191.363-AgR, Rel. Min. Carlos Velloso, julgamento em 3-11-1998, Segunda Turma, DJ de 11-12-1998.

${ }^{15}$ STF, RE 566.836-ED, voto da Rel. Min. Cármen Lúcia, julgamento em 30-6-2009, Primeira Turma, DJE de 14-8-2009 e RE 235.736, Rel. Min. Ilmar Galvão, julgamento em 21-3-2000, Primeira Turma, DJ de 26-5-2000.
} 
De outra ponta, é inconstitucional lei municipal que, consubstanciada na autorização de legislar sobre interesse local, proíbe a instalação de nova farmácia a menos de quinhentos metros de estabelecimento da mesma natureza por ofender aos princípios da livre concorrência, da defesa do consumidor e da liberdade do exercício das atividades econômicas ${ }^{16}$. Ademais, por afronta ao art. 22, inciso VII da Constituição Federal, resulta inconstitucional lei municipal que institui a obrigatoriedade da cobertura de seguro contra furto e roubo de automóveis para as empresas que atuam em área ou local com destinação a estacionamentos ${ }^{17}$, tal como se afigura inconstitucional lei municipal que impõe sanção mais gravosa do que a prevista no Código de Trânsito Brasileiro, por extrapolar a competência legislativa do Município pautada no interesse local ${ }^{18}$. Igualmente, é inconstitucional por invadir a competência legislativa da União (art. 22, inciso IV da CF), lei municipal que instituiu taxa ou contribuição pecuniária sobre o uso e ocupação do solo e do espaço aéreo do Município pelas concessionárias de serviço público, relativa ao espaço ocupado pela instalação dos equipamentos necessários à prestação do serviço objeto da concessão ${ }^{19}$.

$\mathrm{O}$ art. 23 da Constituição Federal estabelece as matérias de atuação administrativa cuja competência seja comum entre a União, os Estados, o Distrito Federal e os Municípios. Trata-se de competências concorrentes administrativas, as quais todos os entes da Federação são competentes para exercê-las, sendo certo que "a prestação do serviço por uma entidade não exclui igual competência de outra - até porque aqui se está no campo da competência-dever, porque se trata de cumprir a função pública de prestação de serviços à população" (SILVA, 2005, p. 273). Em caso de conflito de interesses entre os entes federativos no exercício da competência concorrente administrativa, deve-se utilizar o critério da maior relevância do interesse, já que "mesmo não havendo hierarquia entre os entes que compõem a Federação, pode-se falar em hierarquia de interesses, em que

\footnotetext{
${ }^{16}$ STF, RE 203.909, Rel. Min. Ilmar Galvão, julgamento em 14-10-1997, Primeira Turma, DJ de 62-1998.

${ }^{17}$ STF, RE 313060, Rel. Min. Ellen Gracie, Segunda Turma, julgado em 29-11-2005.

${ }^{18}$ STF, ARE 639.496-RG, Rel. Min. Presidente Cezar Peluso, julgamento em 16-06-2011.

${ }^{19}$ STF, RE 581947, Relator Min. Eros Grau, Tribunal Pleno, julgado em 27/05/2010, Repercussão Geral - Mérito DJe-159 Divulg 26-08-2010 Public 27-08-2010 Ement Vol-02412-05 PP-01113 RT v. 100, n. 904,2011, p. 169-177.
} 
os mais amplos (da União) devem preferir aos mais restritos (dos estados)" (MENDES, 2007, p. 774).

Assentadas as considerações básicas sobre a competência legislativa e administrativa dos Municípios, cumpre destacar as características do exercício poder de polícia desenvolvido no âmbito municipal.

\section{PODER DE POLÍCIA: CONCEITO, ATRIBUTOS E LIMITES}

O poder de polícia é inerente à Administração Pública, constituindose como efeito do princípio da supremacia do interesse público sobre o privado, o qual legitima a imposição de limitações e cerceamentos a direitos de particulares em benefício da coletividade.

Sem adentrar nas divergências doutrinárias sobre a terminologia correta $^{20}$, tem-se que "a atividade de poder de polícia traduz-se na apuração da ocorrência de infrações a deveres da mais diversa ordem, impondo à Administração o poder-dever de promover a apuração do ilícito e a imposição da punição correspondente" (JUSTEN FILHO, 2005, p. 397).

A competência para a imposição aos administrados dessas limitações coercitivas segundo Oliveira (2004, p. 38) "não deflui de texto expresso, mas decorre do poder implícito no contexto normativo", que no caso é justamente a consequência do respeito da supremacia do interesse público sobre o individual.

Os atos materiais que exteriorizam o exercício poder de polícia são atos administrativos, sendo dotados, portanto, dos mesmos atributos inerentes a todos os atos administrativos ${ }^{21}$.

Boa parte da doutrina aponta como atributos dos atos administrativos a presunção de legitimidade e veracidade, a imperatividade, a tipicidade, a exigibilidade e a auto-executoriedade (DI PIETRO, 2002, p. 189).

Pelo atributo da presunção de legitimidade e veracidade, todo ato administrativo possui a presunção relativa (iuris tantum) de que foi realizado

\footnotetext{
20 "É bem verdade que, atualmente, a maioria dos Estados europeus, à exceção a França, abandonaram a expressão 'poder de polícia', para, em sua substituição, adotarem o termo 'limitações administrativas à liberdade e à propriedade'. Porém, o Direito brasileiro ainda continua fiel a esse vocabulário, como podemos constatar, especialmente, na Constituição e no Código Tributário Nacional." (CUNHA JÚNIOR, 2007. p. 57).

21 "O poder de polícia administrativa, quando emanado do Poder Executivo, é um ato administrativo. Possui, portanto, os mesmos atributos de todo ato administrativo: presunção de legitimidade, imperatividade (ou coercibilidade), exigibilidade e auto-executoriedade" (CUNHA JÚNIOR, 2007, p. $60)$.
} 
em conformidade com a lei (legitimidade ${ }^{22}$ ), bem como induz a presunção de que os fatos apontados pela Administração Pública são verdadeiros (veracidade ou fé pública), tal como ocorre com as informações prestadas pela autoridade coatora em sede de mandado de segurança ${ }^{23}$.

A imperatividade é "o atributo que impõe irrestrita obediência aos atos administrativos, independentemente de concordância" (BACELLAR FILHO, 2008, p.73.). A imperatividade dos atos administrativos reside na prescindibilidade da concordância ou anuência dos terceiros afetados pelo ato, já que a Administração Pública os cria unilateralmente ${ }^{24}$.

$\mathrm{O}$ atributo da tipicidade é "a correspondência que o ato deve observar em relação ao seu tipo hipoteticamente definido em lei” (PIRES, 2008, p. 307). A tipicidade se caracteriza pela disposição em lei prévia da conduta repudiada administrativamente, bem como a disposição legal do tipo sancionatório.

A exigibilidade é "a qualidade do ato administrativo que impele o destinatário à obediência das obrigações por ele impostas, sem necessidade de qualquer apoio judicial" (GASPARINI, 2003, p. 72). A característica da exigibilidade não deve ser confundida com o atributo da imperatividade, com bem esclarece Mello (2001, p. 373/374):

Exigibilidade é a qualidade em virtude da qual o Estado, no exercício da função administrativa, pode exigir de terceiro o cumprimento, a observância, das obrigações que impôs. Não se confunde com a simples imperatividade,

\footnotetext{
22 “Ante a presunção de legitimidade, atos administrativos, portanto, sob vestes de direito público, presumem-se verdadeiros e escorreitos, até prova em contrário (presunção juris tantum, e não juris et de jure). Com efeito, como a Administração atua mediante autorização legal, como a atividade administrativa é sublegal, os atos praticados por ela consideram-se escorreitos, firmes, sem qualquer mácula que os possa infirmar. Não fosse assim, cairia por terra toda atividade do Poder Público" (VITTA, 2010, p. 216/217).

${ }^{23}$ Não constitui demasia rememorar, no ponto, que as informações oficiais prestadas por autoridades públicas, em sede de mandado de segurança, revestem-se de presunção "juris tantum" de veracidade. E a razão é uma só: precisamente porque constantes de documento subscrito por agente estatal, tais informações devem prevalecer, pois, como se sabe, as declarações emanadas de servidores públicos gozam, quanto ao seu conteúdo, da presunção de veracidade, salvo quando desautorizadas por prova idônea em sentido contrário (STF, RMS 25849 AgR, Relator(a): Min. Celso de Mello, Segunda Turma, julgado em 12/06/2012, Acórdão Eletrônico DJe-234 Divulg 28-11-2012 Public 29-112012).

24 "É a qualidade que certos atos administrativos têm para constituir situações de observância obrigatória em relação aos seus destinatários, independentemente da respectiva concordância ou aquiescência. Destarte, sempre que o ato administrativo for datado desse atributo, impõe-se mesmo que contrarie os interesses do destinatário [...] Tal qualidade é chamada por Renato Alessi, de poder extroverso do ato administrativo". (GASPARINI, 2003, p. 72).
} 
pois, através dela, apenas se constitui uma dada situação, se impõe uma obrigação. A exigibilidade é o atributo do ato pelo qual se impele à obediência, ao atendimento da obrigação já imposta, sem necessidade de recorrer ao Poder Judiciário para induzir o administrado a observá-la.

Por fim, a auto-executoriedade ou coercibilidade 25 é "a qualidade pela qual o Poder Público pode compelir materialmente o administrado, sem precisão de buscar previamente as vias judiciais, ao cumprimento da obrigação que impôs e exigiu" (MELLO, 2001, p. 374).

O atributo da auto-executoriedade pode estar presente ou não nos atos administrativos derivados do exercício do poder de polícia ${ }^{26}$. Vitta (2010, p. 239/240) esclarece quando será possível a presença da auto-executoriedade nos atos decorrentes do poder de polícia:

Ao revés, na executoriedade há coação direta, ou material, do Poder Público em face do administrado; este se submete, pois, à constrição física do Estado, igualmente sem ordem judicial [...] Contudo, a executoriedade do ato administrativo tem cabimento apenas em duas ordens de casos, a saber: (a) quando a lei expressamente a prevê ou (b) quando ela for indispensável à eficaz garantia do interesse público; ou seja, se não utilizada, haveria grave comprometimento da ordem pública. Entende-se, nesta hipótese, haver autorização implícita do ordenamento para que a Administração possa garantir a proteção do bem jurídico.

Em qualquer hipótese, porém, a auto-executoriedade emanada do exercício do poder de polícia deve ser exercida sem excessos ilícitos prejudiciais aos direitos fundamentais, que somente serão restringidos em benefício ao interesse público na medida necessária para a finalidade almejada ${ }^{27}$.

\footnotetext{
25 "A polícia administrativa, como é natural, não pode curvar-se ao interesse dos administrados de prestar ou não obediência às imposições. Se a atividade corresponder a um poder, decorrente do ius imperii estatal, há de ser desempenhada de forma a obrigar todos a observarem os seus comandos. Diga-se, por oportuno, que é intrínseco a essa característica o poder que tem a Administração de usar a força, caso necessária para vencer eventual recalcitrância". (CARVALHO FILHO, 1999, p. 55).

26 "A auto-executoriedade não existe em todas as medidas de polícia. Para que a Administração possa se utilizar dessa faculdade, é necessário que a lei a autorize expressamente, ou que se trate de medida urgente, sem a qual poderá ser ocasionado prejuízo maior para o interesse público". (DI PIETRO, 2002, p. 115).

27 "O poder de polícia pode acarretar disciplina e restrições ao exercício de um direito fundamental em benefício do interesse público. Ao mesmo tempo, o reconhecimento de direitos fundamentais configura limite ao poder de polícia: os direitos fundamentais não podem ser suprimidos. Nem sempre apresenta-se fácil situar o ponto onde começa a violação dos direitos fundamentais pelo exercício do poder de polícia”. (MEDAUAR, 2004, p. 400).
} 
Parte da doutrina (DI PIETRO, 2002, p. 113/114) aponta que o poder de polícia, além dos atributos inerentes aos atos administrativos, possui como atributo, em regra, a discricionariedade ${ }^{28}$. Essa discricionariedade é relativa à conveniência da Administração Pública em definir legislativamente quais serão as limitações administrativas impostas aos particulares, bem como a definição das sanções administrativas e o procedimento administrativo no caso da aplicação dessas sanções. Uma vez definidas por lei as situações acima descritas, o exercício do poder de polícia se torna vinculado. Como visto, a discricionariedade não está presente em todo ato decorrente do exercício do poder de polícia. Nesse sentido as palavras de Meirelles (2004, p. 134):

Observe-se que o ato de polícia é, em princípio, discricionário, mas passará a ser vinculado se a norma legal que o rege estabelecer o modo e forma de sua realização [...]. Ao conceituarmos o poder de polícia como faculdade discricionária não estamos reconhecendo à Administração qualquer poder arbitrário. Discricionariedade não se confunde com arbitrariedade. Discricionariedade é liberdade de agir dentro dos limites legais; arbitrariedade é ação fora ou excedente da lei, com abuso ou desvio de poder.

É importante ressaltar que, para a finalidade do presente estudo, o conceito de atributo é sinônimo de característica. E como característica, pode estar ou não presente quando do exercício do poder de polícia (PIRES, 2008, p. 307).

Um típico instrumento de concretização do exercício do poder de polícia pela Administração Pública é a lavratura de multas pecuniárias. A multa administrativa em razão do exercício do poder de polícia possui dupla função. A primeira função é inibitória ou preventiva, já que visa coibir práticas vedadas por lei. A segunda função é repressiva ou punitiva, visando sancionar o ato comissivo ou omissivo praticado pelo particular em desconformidade com a lei. Como afirmado por Meirelles (2004, p. 137), "o poder de polícia seria inane e ineficiente se não fosse coercitivo e não estivesse aparelhado de sanções para os casos de desobediência à ordem legas da autoridade competente”.

\footnotetext{
${ }^{28}$ Em sentido contrário: "Portanto, é incorreto qualificar o poder de polícia como um 'poder discricionário'. Em primeiro lugar, porque não existe essa categoria de 'poder discricionário'. Há competências administrativas disciplinadas por lei, as quais podem contemplar margem de discricionariedade. Depois, as competências de poder de polícia envolvem tanto disciplina discricionária como vinculada. O poder de polícia é integrado não apenas por competências discricionárias. Há inúmeras atribuições que são reguladas de modo vinculado pela lei”. (JUSTEN FILHO, 2005, p. $393)$.
} 
Em interessante estudo, Pérez (2012) descreve a influência dos bons costumes nos limites do poder de polícia exercido no controle da publicidade empresarial espanhola:

La acción administrativa de intervención o policía en su más amplio sentido, se concreta en una serie de limitaciones de la actividad de los particulares. Son muchas las manifestaciones de esta acción administrativa con la finalidad de mantener la moral y buenas costumbres, en diversos ámbitos. En los Tratados y Manuales tradicionales de Derecho administrativo no faltaba en la parte especial, um capítulo dedicado a la llamada 'policía de la moralidad'o 'policía de costumbres '-.La Ley General de Publicidad (Ley 34/1988, de 11 de noviembre) considera ilícita "la publicidad que atente contra la dignidad de la persona o vulnere los valores y derechos reconocidos en la Constitución, especialmente en lo que se refiere a la infancia, la juventud y la mujer, así como 'la publicidad subliminal' (art. $3^{\circ}$, a y d), calificando subliminal 'la que mediante técnicas de producción de estímulos de intensidades fronterizas con los umbrales de los sentidos o análogos, pueda actuar sobre el público destinatario sin ser conscientemente percibidos' (art. 7), no siendo infrecuente la utilización de esta última para promover servicios contrarios a la moral o, al menos, a determinadas concepciones morales.

Destacado o conceito de poder de polícia, bem como apontados os seus atributos e os seus limites, cumpre analisar o uso específico do poder de polícia municipal para a defesa de direitos metaindividuais.

\section{A UTILIZAÇÃO DO PODER DE POLÍCIA MUNICIPAL COMO INSTRUMENTO DE DEFESA DE DIREITOS DIFUSOS E COLETIVOS}

Demonstrada a competência legislativa e administrativa do Município, bem como as características do poder de polícia, cabe a análise de algumas situações concretas que o Município, através da utilização do seu poder de polícia, pode atuar na defesa de interesses metaindividuais sem a necessária intervenção prévia do Poder Judiciário.

O Município exerce seu poder de polícia quanto às matérias de sua competência administrativa e legislativa ${ }^{29}$, em especial com a finalidade de promover a fiscalização da correta execução da lei pelos particulares e, caso necessário, promover a aplicação de sanções administrativas às condutas

\footnotetext{
29 "Deve-se, em conclusão, entender que a atividade de polícia administrativa incumbe a quem legisla sobre a matéria, ficando, todavia, claro que a competência legislativa da União sobre os assuntos relacionados no art. 22 não exclui competência municipal ou estadual, e, portanto, não exclui o poder de polícia destes, quanto aos aspectos externos à essência mesma da matéria deferida à União" (MELLO, 2001, p. 709).
} 
delituosas no tocante à saúde, ao transporte público, ao uso e ocupação do solo urbano, à publicidade empresarial local, ao sossego público, ao meio ambiente, ao consumidor e ao funcionamento e instalação de estabelecimentos em seu território.

Para o presente estudo, será abordada a tutela coletiva através do exercício do poder de polícia municipal do direito ao transporte coletivo seguro e eficiente e ao direito à ocupação regular do solo urbano.

Quanto à tutela do transporte coletivo municipal, é possível ao Município, além da cominação de multa administrativa, proceder à apreensão de veículo utilizado de forma irregular por particulares para transporte público clandestino de passageiros ${ }^{30}$. Tal medida visa à proteção do direito ao transporte público eficiente e seguro, coibindo particulares de circularem com veículos não autorizados pelo Poder Público para uso coletivo, uma vez que não foram submetidos a vistorias a cargo do órgão competente com a finalidade de aferir a obediências às normas de segurança dos veículos, além da correta qualificação técnica do transportador ${ }^{31}$.

Quando houver a apreensão de veículo utilizado para o transporte remunerado de pessoas ou bens que não foi licenciado para esse fim, nos termos do art. 231, inciso VIII do Código de Trânsito Brasileiro, a liberação do veículo retido por transporte irregular de passageiros não está condicionada ao pagamento de multas e despesas ${ }^{32}$.

Note-se que existem decisões judiciais ${ }^{33}$ que, com base no art. 107 do Código de Trânsito Brasileiro, diferenciam o poder de polícia de trânsito do chamado poder de polícia do transporte ${ }^{34}$. Enquanto o poder de polícia de trânsito

\footnotetext{
${ }^{30}$ TJSP - Apelação n ${ }^{\circ}$ 0117036-26.2008.8.26.0506 - Comarca de São Paulo - 6 ${ }^{\mathrm{a}}$ Câmara de Direito Público - Rela. Desa. Maria Olívia Alves - DJ. 10.06.2013.

${ }^{31}$ TJSP - Apelação n ${ }^{\circ}$ 9154609-22.1999.8.26.0000 - 2 ${ }^{\mathrm{a}}$ Câmara de Direito Público - rel. Des. Paulo Sunao Shintate - DJ. 27.03.2001 e TJSP - Apelação n ${ }^{\circ}$ 9035026-77.1998.8.26.0000 - $1^{\text {a }}$ Câmara de Direito Público - rel. Des. Demóstenes Miguelino Braga - DJ. 29.10.1999.

${ }^{32}$ STJ, REsp 1144810/MG, Rel. Min. Teori Albino Zavascki, DJe de 18.3.10 e AgRg no REsp 1303711/RJ, Rel. Ministro Castro Meira, DJe 29/08/2012.

${ }^{33}$ TJSP - Apelação n ${ }^{\circ}$ 0040551-88.2011.8.26.0114 - Comarca de Campinas - $2^{\text {a }}$ Câmara de Direito Público - Rel. Des. Cláudio Augusto Pedrassi - DJ. 16.04.2013.

${ }^{34}$ Meirelles (2008, p, 455), sustenta opinião diferente, no sentido de que o Município exerce poder de polícia tipicamente de trânsito quanto ao transporte exercido em sua circunscrição, não mencionando fazenda qualquer diferenciação entre poder de polícia de trânsito e poder de polícia de transporte coletivo: "E assim na generalidade das nações civilizadas que reconhecem às comunidades locais o direito-dever de zelar pela circulação e pelo transporte em seu território, preservando seu sistema viário urbano e rural contra o congestionamento do trânsito e os excessos do tráfego. Todas as medidas de ordenamento da circulação e dos transportes no território municipal são da competência do Município, porque visam no dizer autorizado de Hodges ao controle do tráfego na via pública: the traffic control in the public street".
} 
é relativo à competência para regular o procedimento de habilitação para dirigir, bem como para deliberar sobre a circulação de automotores, pedestres, a sinalização das vias, o registro e o licenciamento dos veículos, o poder de polícia do transporte atua sobre a competência para regular o transporte coletivo no âmbito municipal, cuja atribuição é conferida expressamente pela Constituição Federal aos Municípios ${ }^{35}$ (art. 30, inciso V da Constituição Federal).

Como visto, a retenção por parte do Município de veículos de transporte público irregulares, sem a intervenção do Poder Judiciário determinando a sua busca e apreensão, mostra-se possível para a finalidade de preservar a imediata segurança dos passageiros envolvidos.

Já no que concerne ao direito à ocupação regular do solo urbano, o Município é competente para promover o adequado ordenamento de seu território, bem como o uso e parcelamento do seu solo urbano (art. 30, inciso VIII da CF).

A melhor exegese do art. 40 da Lei $n^{\circ}$ 6.766/79 atribuiu ao Município a responsabilidade na fiscalização e na regularização de eventuais loteamentos irregulares ou clandestinos instalados em sua área urbana ${ }^{36}$. Cumpre apontar que não basta somente ao Município expedir notificações ou aplicar multas aos responsáveis pelo loteamento realizado em desacordo com as leis urbanísticas. Faz-se necessária a regularização efetiva do loteamento irregular pelo Município, sob pena de ser responsabilizado por sua omissão ${ }^{37}$. Quanto ao assunto, contudo, o Superior Tribunal de Justiça, possui recente precedente em sentido contrário, alterando sua jurisprudência sobre o tema, entendendo que o art. 40 da Lei ${ }^{\circ}$ 6.766/79 encarta uma conduta discricionária do Município, não cabendo ao Poder Judiciário determinar a realização das obras para regularização do loteamento irregular ${ }^{38}$.

\footnotetext{
${ }_{35}$ TJSP - Apelação $n^{\circ}$ 0055777-36.2011.8.26.0114 - Comarca de Campinas - $7^{\text {a }}$ Câmara de Direito Público - Rel. Des. Luiz Sérgio Fernandes de Souza - DJ. 18.12.2012.

${ }^{36}$ STJ, REsp 131.697/SP, Rel. Ministro João Otávio de Noronha, Segunda Turma, DJ. 07.04.2005.

${ }^{37} \mathrm{O}$ fato de o município ter multado os loteadores e embargado as obras realizadas no loteamento em nada muda o panorama, devendo proceder, ele próprio e às expensas do loteador, nos termos da responsabilidade que lhe é atribuída pelo art. 40 da Lei 6.766/79, à regularização do loteamento executado sem observância das determinações do ato administrativo de licença. No caso, se o município de São Paulo, mesmo após a aplicação da multa e o embargo da obra, não avocou para si a responsabilidade pela regularização do loteamento às expensas do loteador, e dessa omissão resultou um dano ambiental, deve ser responsabilizado, conjuntamente com o loteador, pelos prejuízos dai advindos, podendo acioná-lo regressivamente. (STJ, REsp 1113789/SP, Rel. Ministro Castro Meira, Segunda Turma, DJ. 16.06.2009).

${ }^{38} \mathrm{O}$ art. 40 da Lei n. 6.766/1979 confere ao município a faculdade de promover a realização de obras de infra-estrutura em loteamento, sob seu o critério de oportunidade e conveniência. (STJ, REsp 859.905/RS, Rel. Ministro Mauro Campbell Marques, Rel. p/ Acórdão Ministro Cesar Asfor Rocha, Segunda Turma, DJ. 01.09.2011).
} 
Interessante exemplo na eficiência do exercício do poder de polícia municipal, sem a necessária intervenção judicial, pode ser obtido em relação à regulamentação do uso e da ocupação do solo urbano, em especial quanto aos núcleos habitacionais precários, instalados normalmente em áreas públicas. Quando constatada pelo Município a invasão e a construção de assentamentos em áreas públicas ou de risco, bem como em áreas ambientais protegidas por lei, a imediata remoção dos invasores e demolição do que foi recentemente construído é claramente mais vantajoso, seja no aspecto social ou jurídico, do que buscar junto ao Poder Judiciário uma medida judicial no mesmo sentido, uma vez que, diante de uma realidade social dinâmica e até o efetivo cumprimento da ordem judicial, tem-se que muitas outras famílias já tenham construído suas casas no local, mormente estimuladas pela inércia do Poder Público na resolução célere do problema. Tal situação potencializa o dano e dificulta a solução do conflito em virtude da coletivização da invasão e pelo transcurso de um lapso temporal razoável para desocupação da área, sendo importante lembrar o que ocorreu em 22 de janeiro de 2012, quando houve a execução de uma decisão judicial de reintegração de posse em favor da massa falida do grupo Selecta S/A, onde dois mil soldados da Polícia Militar de São Paulo desalojaram cerca de 1.600 famílias que ocupavam um terreno de 1,3 milhão de metros quadrados em São José dos Campos/SP, onde existia o assentamento precário chamado de favela do Pinheirinho (AGÊNCIA SENADO, 2012).

É claro que não basta a mera remoção das pessoas envolvidas e a demolição das construções erguidas, devendo o poder de polícia exercido pelo Município servir somente de ponto inicial para a implementação de políticas públicas de habitação social. Em qualquer hipótese, saliente-se, a remoção sempre deverá ser pautada pela razoabilidade na escolha das medidas administrativas adotadas para o caso concreto.

Para tanto, a título exemplificativo, vale apontar o ocorrido na cidade de Ribeirão Preto no Estado de São Paulo, onde, conjuntamente com o projeto não governamental "Moradia Legal", foi promovida à regularização fundiária de diversos assentamentos irregulares da cidade, entre estes os localizados no Jardim Monte Alegre, no Jardim Progresso e no Jardim Aeroporto. Conforme informações obtidas na página eletrônica do projeto Moradia Legal (http:// www.moradialegal.com.br), projeto social idealizado, criado e implantado pelos Juízes de Direito João Agnaldo Donizeti Gandini e Júlio César Spoladore Dominguez no ano de 2005, as favelas da cidade foram sobrevoadas, 
identificadas e fotografadas, realizando-se estudos sociais, com a identificação das características principais das famílias (idade, sexo, formação, origem, qualificação profissional, etc), publicando-se no diário oficial do Município uma lista de moradores naquele período que futuramente seriam incluídos preferencialmente em projetos habitacionais.

O primeiro núcleo a ser objeto de intervenção foi a favela do Jardim Monte Alegre, com aproximadamente 420 famílias, sendo o recurso financeiro assegurado no orçamento municipal (cerca de três milhões de reais). Feito isso, a intervenção teve início, transferindo-se cerca de noventa famílias para um núcleo habitacional dotado da infraestrutura básica, como fornecimento de água e coleta e tratamento de esgoto, pavimentação asfáltica, guias de sarjeta, captação de águas pluviais e iluminação pública. Mediante uma parceria realizada com uma empresa privada, foram doados equipamentos como postes de energia, relógio, fiação, lâmpadas elétricas, chuveiro ecológico e geladeira nova para todas as 420 famílias. O projeto "Moradia Legal" recebeu o prêmio do Instituto Innovare na categoria de juiz individual no ano de 2008.

Assim, em que pese a existência de divergência sobre o assunto ${ }^{39}$, mostrase possível ao Município, através do exercício do seu poder de polícia decorrente da sua competência constitucional quanto à matéria relativa ao uso e ocupação do solo urbano, proceder à remoção de pessoas e demolição de construções realizadas em áreas públicas, áreas de risco para os ocupantes ou áreas ambientalmente protegidas ${ }^{40}$.

É claro que a possibilidade do exercício do poder de polícia nessas condições, sem a intervenção prévia do Poder Judiciário, somente existe quando a remoção das pessoas envolvidas ou a demolição das construções ocorrer pouco tempo após a invasão da área - e não em área ocupadas já consolidadas

\footnotetext{
${ }^{39} \mathrm{O}$ poder de polícia do Município e auto-executoriedade dos atos administrativos não afastam a necessidade da prestação jurisdicional para a demolição das edificações. (TJSP - Apelação $\mathrm{n}^{\circ} 9103702-$ 28.2008.8.26.0000 - rel. Des. Torres de Carvalho - DJ. 13.12.2012).

${ }^{40}$ Invasão de área pública Notificação para a desocupação respectiva, sob pena de imissão forçada na posse [...] Imissão forçada na posse da área que decorre do exercício do poder de polícia administrativo Auto-executoriedade dos atos administrativos, como atributo do poder de polícia Desnecessidade de intervenção judicial. (TJSP - Apelação $\mathrm{n}^{\circ}$ 9116111-02.2009.8.26.0000 - Comarca de São Paulo - 12 $2^{\mathrm{a}}$ Câmara de Direito Público - rel. Des. Osvaldo de Oliveira - DJ. 23.11.2011). No mesmo sentido: Conforme disposto pelo art. 72, parágrafo $7^{\circ}$, da Lei Federal n. ${ }^{\circ}$ 9.605/1998, integra o elenco das sanções restritivas de direitos postas em mãos da Administração Pública, em exercício de seu poder de polícia, a demolição de obra que não tenha obedecido às determinações legais ou regulamentares [...] Diante do poder - e mesmo dever - de o IBAMA proceder à demolição das obras que estejam em desacordo com as determinações legais e regulamentares, induvidosa é a desnecessidade da tutela jurisdicional fomentada. (TRF da $5^{\text {a }}$ Região - Apelação $n^{\mathrm{o}}$ 0006330-36.2004.4.05.8200, a $^{\mathrm{a}}$ Turma - rel. Des. Federal Cesar Carvalho, - DJ. 08.03.2007).
} 
há um tempo considerável - sendo os atos dessa remoção pautados pela proporcionalidade e razoabilidade.

Quando se tratar da invasão de áreas públicas ou ambientalmente protegidas, somente será lícita a demolição das construções recentemente erguidas, consideradas como aquelas que ainda não assumiram a conotação de domicílio dos invasores, como forma de respeitar, assim, o direito fundamental à inviolabilidade do domicílio ${ }^{41}$ (art. $5^{\circ}$, inciso XI da $\mathrm{CF}$ ) e o direito à propriedade (art. $5^{\circ}$, inciso XXII da CF). A utilização da razoabilidade e da proporcionalidade também deve ser feita na análise administrativa quanto à real configuração do local como domicílio ou não dos invasores, considerando-se, entre outros pontos, se o local serve de regular habitação dos ocupantes. ${ }^{42}$

Já na situação de construções erguidas em área de risco aos ocupantes, como em áreas alagadiças ou em áreas sujeitas a desabamentos, a eventual demolição das construções deverá ser feita independentemente do critério da configuração de domicílio, haja vista a própria Constituição Federal excepcionar a inviolabilidade de domicílio nestas situações ${ }^{43}$ (art. $5^{\circ}$, inciso XXV da CF). Importa destacar que o art. $3^{\circ}-B, \S 3^{\circ}$ da Lei $n^{\circ}$

\footnotetext{
${ }^{41}$ Sendo assim, ninguém, especialmente a autoridade pública, pode penetrar em casa alheia, exceto (a) nas hipóteses previstas no texto constitucional ou (b) com o consentimento de seu morador, que se qualifica, para efeito de ingresso de terceiros no recinto doméstico, como o único titular do respectivo direito de inclusão e de exclusão. Impõe-se destacar, por necessário, que o conceito de "casa", para os fins da proteção jurídico-constitucional a que se refere o art. $5^{\circ}$, XI, da Lei Fundamental, reveste-se de caráter amplo, pois compreende, na abrangência de sua designação tutelar, (a) qualquer compartimento habitado, (b) qualquer aposento ocupado de habitação coletiva e (c) qualquer compartimento privado onde alguém exerce profissão ou atividade. Esse amplo sentido conceitual da noção jurídica de "casa" revela-se plenamente consentâneo com a exigência constitucional de proteção à esfera de liberdade individual e de privacidade pessoal (STF, SS 1203, Relator Min. Celso de Mello, julgado em 08/09/1997, publicado em DJ 15.09.97).

42 "O princípio da proporcionalidade deriva, de certo modo, do poder de coerção de que dispõe a Administração ao praticar atos de polícia. Realmente, não se pode conceber que a coerção seja utilizada indevidamente pelos agentes administrativos, o que ocorreria, por exemplo, se usada onde não houvesse necessidade [...] Não havendo proporcionalidade entre a medida adotada e o fim a que se destina, incorrerá a autoridade administrativa em abuso de poder e ensejará a invalidação da medida na via judicial, inclusive através de mandado de segurança. Na verdade, sobram razões para esse entendimento. Mas a principal, segundo nosso entender, descansa no postulado maior pelo qual à Administração são conferidas prerrogativas que têm o único escopo de atender aos interesses coletivos, não lhe sendo lícito, todavia, atuar em detrimento deste ou daquele indivíduo, a pretexto de buscar aqueles interesses". (CARVALHO FILHO, 1999, p. 56).

43 "Os moradores de áreas de risco, na ocorrência de desastres podem ser retirados de suas residências pela atuação dos agentes de Defesa Civil na resposta e prevenção de desabamentos de imóveis, ações estas amparadas nos regulamentos e normas do Ministério da Integração Nacional. O Poder Público pode se valer de mecanismos presentes em lei para atuar em casos de situação de risco social. É o caso de desocupação de um imóvel situado em área de risco, pois caracteriza que a propriedade está em situação de perigo público iminente e pode ocorrer requisição pelo Poder Público, em consonância com a Constituição Federal de 1988, art. 5º inciso XXV”. (PEREIRA, 2012, p. 41/42).
} 
12.340/2010, acrescido pela Lei $n^{\circ} 12.608 / 2012$, estabelece que aqueles que tiveram suas moradias removidas por se encontrarem em áreas suscetíveis à ocorrência de deslizamentos de grande impacto, inundações bruscas ou processos geológicos ou hidrológicos correlatos, deverão ser abrigados quando necessário, bem como deverão ser cadastrados pelo Município para garantia de atendimento habitacional em caráter definitivo, de acordo com os critérios dos programas públicos de habitação de interesse social. Igualmente, na hipótese de remoção de edificações, o Poder Público deverá adotar medidas que impeçam a reocupação da área $\left(\S 2^{\circ}\right.$ do art. $3^{\mathrm{a}}-$ B da Lei $\left.n^{\circ} 12.340 / 2010\right)$.

Por fim, como já anteriormente dito, a mera remoção de pessoas das áreas em questão sem o seu devido cadastramento em programas habitacionais e em programas de assistencialismo social não adiantará de nada para a solução do conflito social, já que as pessoas continuarão sem local para habitar e sem perspectiva de uma vida minimamente digna, ocasionando apenas a mudança da área invadida para outra área a ser futuramente ocupada.

\section{CONSIDERAÇÕES FINAIS}

Como demonstrado ao longo do texto, é recomendável ao Município, através do exercício do seu poder de polícia, promover a tutela coletiva dos direitos metaindividuais decorrentes da sua competência constitucional administrativa e legislativa.

A desnecessidade de intervenção do Poder Judiciário decorrente do atributo da auto-executoriedade, presente em alguns casos do exercício do poder de policia, ocasiona uma benéfica desjudicialização dos conflitos sociais passíveis de solução administrativa, uma vez que proporciona uma resposta mais rápida da Administração Pública frente a conflitos que poderiam se agravar em razão da demora na adoção de medidas protetivas, privilegiando, assim, o princípio administrativo da eficiência.

Igualmente, por vezes o Poder Judiciário se encontra alheio às tensões locais da realidade social, mormente quando for escassa a instrução probatória do processo, circunstância esta que difere da condição da Prefeitura, dotada geralmente de servidores públicos qualificados para a maioria das situações onde o exercício do poder de polícia se faz necessário para a solução do conflito, como assistentes sociais, fiscais, guardas civis, agentes do controle de vetores, entre outros servidores. 
Entre todas as situações expostas, em especial na tutela coletiva do direito ao transporte público seguro e eficiente e do direito à ocupação regular do solo urbano, pode-se notar que a regularidade no exercício do poder de polícia para a defesa de direitos metaindividuais se caracteriza pela presença da urgência na adoção da medida administrativa, sob pena de resultar dano maior aos direitos envolvidos em face da demora de eventual intervenção do Poder Judiciário. Igualmente, deve estar presente o postulado da proporcionalidade na escolha das medidas administrativas derivadas do poder de polícia, como forma de evitar o sacrifício desnecessário de parte de direitos do particular que não influenciaram na ocorrência de danos ao direito metaindividual protegido, mas que poderiam sofrer inadvertidamente os efeitos das sanções administrativas aplicadas.

\section{REFERÊNCIAS}

AGÊNCIA SENADO. Entenda o caso Pinheirinho. Agencia Senado, 23 fev. 2012. Disponível em: $<$ http://www12.senado.gov.br/noticias/materias/ 2012/02/23/entenda-o-caso-pinheirinho>. Acesso em: 9 maio 2012.

ALVES, Francisco de Assis. Autonomia municipal e interesse local como parâmetros à competência legislativa dos Municípios. Revista da Faculdade de Direito de Campos, Ano 4, n. 4, Ano 5, n, 5, . p. 527-581, 2003-2004.

BACELLAR FILHO, Romeu Felipe. Direito Administrativo. 4. ed. São Paulo: Saraiva, 2008.

CARVAlHO FILHO, José dos Santos. Manual de Direito Administrativo. 2. ed. Rio de Janeiro: Lúmen Júris, 1999.

CUNHA JÚNIOR, Dirley da. Curso de direito administrativo. 5. ed. Salvador: Juspodivm, 2007.

DI PIETRO, Maria Sylvia Zanella. Direito Administrativo. 14. ed. São Paulo: Atlas, 2002.

GASPARINI, Diógenes. Direito Administrativo. 8. ed. São Paulo: Saraiva, 2003. 
GERAIGE NETO, Zaiden. O princípio da inafastabilidade do controle jurisdicional. São Paulo: Revista dos Tribunais, 2003.

JUSTEN FILHO, Marçal. Curso de Direito Administrativo. São Paulo: Saraiva, 2005.

MEDAUAR, Odete. Direito Administrativo Moderno. 8. ed. São Paulo: Revista dos Tribunais, 2004.

MEIRELLES, Hely Lopes. Direito Municipal Brasileiro, 16. ed. São Paulo: Malheiros, 2008.

MEIRELLES, Hely Lopes. Direito Administrativo Brasileiro. 29. ed. São Paulo: Malheiros, 2004.

MELlO, Celso Antônio Bandeira de. Curso de Direito Administrativo, 13. ed. São Paulo: Malheiros, 2001.

MENDES, Gilmar Ferreira; COELHO, Inocêncio Mártires; BRANCO, Paulo Gustavo Gonet. Curso de Direito Constitucional. São Paulo: Saraiva, 2007.

MORAES, Alexandre de. Direito Constitucional. 11. ed. São Paulo: Atlas, 2002.

OLIVEIRA, Régis Fernandes de. Taxa de Polícia. 2. ed. São Paulo: Revista dos tribunais, 2004.

PECHIR, Om Christian Alvarado. El control de la administración pública municipal como una opción hacia la modernización administrativa. In: FARÍAS, Germán Cisneros (Coord.). Control de la administración pública Segundo Congreso Iberoamericano de Derecho Administrativo. México: Editora da Universidad Nacional Autónoma de México, 2007.

PEREIRA, Aparecida Veloso; BARBOSA, Fernando Cordeiro. Aspectos jurídicos relativos às desocupações de moradias em áreas de risco em 
decorrência de desastres. Revista Direito, Estado e Sociedade, Rio de Janeiro, n. 41, p. 30-51, jul/dez., 2012.

PÉREZ, Jesús González. Administración Pública y Moral. Disponível em: $<$ http://www. racmyp.es/docs/anales/A72/A72-1.pdf $>$. Acesso em: 19 abr. 2012.

PIRES, Luis Manuel Fonseca. O controle epidemiológico da dengue e a inviolabilidade do domicílio. In: MARINELA, Fernanda; BOLZAN, Fabrício (Coord.). Leituras Complementares de Direito Administrativo: Advocacia Pública. Salvador: Juspodivm, 2008.

SILVA, José Afonso da. Comentário Contextual à Constituição. São Paulo: Malheiros, 2005.

SILVA, José Afonso da. Curso de Direito Constitucional Positivo. 13.ed. São Paulo: Malheiros, 1997.

SILVA, Sandra Krieger Gonçalves. O Município na Constituição Federal de 1988: autonomia, competência legislativa e interesse social. São Paulo: Editora Juarez de Oliveira, 2003.

VITTA, Heraldo Garcia. Poder de Polícia. São Paulo: Malheiros, 2010.

Artigo recebido em: 29/10/2013 Aprovado para a publicação em: 28/11/2013

Como citar: MAZZEI, Marcelo Rodrigues. LORENZI, Marcelo Tarlá. GERAIDEN, Zaiden Neto. A defesa de direitos coletivos e difusos através do exercício do poder de polícia municipal: o direito ao transporte coletivo seguro e o direito à ocupação regular do solo urbano. Revista do Direito Público. Londrina, v.8, n.3, p.233-252, set./dez. 2013. DOI: 10.5433/ 1980-511X.2013v8n3p233. 